\title{
THE MASCULINITY OF MADURESE MALE BODIES IN PATRIARCHAL CULTURE
}

\author{
Kamalia Novi \\ Doctoral Program of Social Sciences, Faculty of Social Sciences and Politics, \\ University of Airlangga, Surabaya, Indonesia \\ E-mail: aby novy@yahoo.com
}

\begin{abstract}
Power, just like the one discussed by Foucault, is a social, cultural, economic, and political construction, especially those in relation to gender and power between men and women in the domestic circle. Foucault confirmed that inside the body, power or authority becomes a tool of power to dominate and to be dominated (the politics of the body). It works by controlling, restraining, and dominating. In Madura, women are the main determinant in cultural and social recognition of male masculinity. It is because women are those among the first who create and give control and power to call the men (whom they marry) as lake' or tak lake'. The term of tak lake' not only marks the disappearance of the biological function of maleness, but also the loss of a man's "self-esteem" in this highly patriarchal culture. The more terrible thing is when this predicate of tak lake' triggering the so'ler. How does the political body of so'leran constructs the gender relations of Madurese men and women in the domestic circle? Together with descriptive qualitative methods, the researcher deepens this research by using Foucault's genealogical perspective. Meanwhile, a case study approach is also used for this research. In this research, the researcher finds the fact that the political body of so'leran is made and divided into two ways, namely discipline and panopticon. Another fact is that the relationship of power and knowledge of the Madurese male masculinity discourse has punished the body of a man by calling it tak lake', for it is unable to meet the expectations of masculinity constructed by Madurese society.
\end{abstract}

\section{KEY WORDS}

Foucault, masculinity, patriarchy, so'leran, politics of the body.

In the 1980s, in developed countries, men had the same tendency as women with their thoughtfulness and tenderness. These men were mostly from the middle classes, well educated, and intellectual. While in the 1990s, men showed their masculinity through football, free sex, and their ability to have fun. And these metrosexual men finally became the type of man in the era of 2000s and until now, as a portrait of the life switch where men turned into spectacle. This change in male masculinity from time to time is an evidence of the effects of social construction, which mostly came through media and advertising (Mohammed, 2011, Lynne, 2010, Trikuncoro, 2013, Sondakh, 2014). As a concept of social construction, masculinity (as well as femininity) is not a private property, rather, it is seen as a structural property of the social system arising from social interactions involving various values that develop in society, where men are portrayed with rationality, active, competitive and aggressive, while women are depicted otherwise (Rosalina, 2012).

This construction is called hegemonic masculinity, which is the influence of the dominance of a construction of masculinity over other forms of masculinity, or a form of social domination of masculinity in a particular culture within a certain period of time (Connell, 2005, Trigiani, 2008, Sasmita, 2017 \& Drianus, 2019). It means that hegemonic masculinity, not only subordinates women, but also dominates other men. It is because as a result of hegemonic masculinity, a lot of men were then depressed because of the demands of society towards him (Wardani, 2018)

In Madura, the construction of the physical values of male masculinity is characterized by a muscular body, sturdy, strong, manly and not impotent. Meanwhile, in the construction of social values, Madurese men are required to have high responsibilities, dare to maintain their self-esteem, be honest, and also faithful or loyal. The cultural value of Madurese male 
masculinity is that in addition to being able to protect and maintain his manliness (having many children), at a certain point, also in their ability of doing carok (kill people who have insulted his pride) to those who have disturbed his wife. In Madurese tradition, a wife is a man's pride. (Wiyata, 2002)

The failure of Madurese men to meet their masculinity expectations as explained above, resulted in him being called tak lake' (not macho, not manly, not masculine). It is the same as the failure of the man in becoming the head of his family because he could not maintain the integrity of his household from the causes of destruction and even separation. Man's social failure is related to the failure in fulfilling the duties and obligations as a head of the family by providing the household needs. While failing in physical value, is failing to fulfill the wife's sexual expectations, because of 'losing' in a 'bed battle' or failing to make the wife pregnant (do not have children), aka impotent.

For this failure, in Madura's term, men are called as jubheng alias unproductive, weak, sickly and defeated. If so, the wife has the power to divorce the man. And if the woman who divorced him remarries, the man will experience what is called as so'ler. In this case, so'ler means that the woman replaces her husband with the body of another man who becomes her new husband. The term tak lake' does become more thickly attached to the divorced man when the new husband of the woman is in a "better" position than him in all matters, both financially and virility (in the conception of masculinity in Madurese society).

The predicate of tak lake' became the most appalling thing for Madurese men, as it marked not only the disappearance of biological functioning of men, but also the loss of a man's "self-esteem" in the face of his highly patriarchal culture. This understanding is similarly proportional to the masculinity of the people of Nairobi in Africa. Through Kageha and Moyer's writings entitled 'Putting Sex on The Table,' it is understood that men in Nairobi society do have pressure to satisfy their wives in terms of sexuality. A man's sexual ability is one of the important benchmarks of their masculinity.

Thus, to maintain their masculinity, especially those related to the body directly, Madurese men use various strategies so as not to 'lose' in their 'bed battles' such as consuming 'strong' herbs or tonic (obat kuat), hajar jahannam, and masseur services (Bustami, 2006). This is because bed is considered a battle arena for dominance between women and men since ancient times. If a man is unable to fulfill his partner's sexual desire expectations, then the woman has a reason to divorce him, and then replaces him with a younger, stronger, and more powerful male body. In this case, bed is understood not only as a battle arena for the desires of two partners, but also as a battle place of ideology, character, mentality and also power, because according to Foucault (1997: 25-27) sex (bed activity) cannot be separated from power, and the body becomes the area where the power relation runs on it.

The ones being experienced by the so'leran body is what is called as the politics of the body. Where the body becomes the object of power and is regulated by society; it is shunned, despised, rejected, reviled, banished, manipulated, repressed, controlled, and judged both with attitude (acts) and with narration (words). So'leran body is no longer valuable and has to endure solitude even until it dies. The tak lake' body will be rejected by the community's cultural system by being referred to as a damaged body and potentially leading to problems in the household, especially for his future wife.

The rejection of the soleran body who wants to remarry is more due to the belief of some Madurese people in one of the factors that determine the happiness of marriage; the affairs of bed and body. Besides being able to fulfill his wife's sexual expectations, a Madurese man must also be able to make his wife pregnant. It means that Madurese men should not be impotent, because the purpose of marriage in Madurese society is to have offspring.

This Madurese culture is likely similar to what happened in England in the 17th century, where Thomas Foster (1999) said that during that time, there was a dominance of the reproductive imperative. At that time, all married couples must have their own descendants, and if there are couples who were not procreative, it will be criminalized through court proceedings and divorce. 
Foster (1999) stated that a man's inability to 'please' his wife in 'bed' is just as bad as his inability to reproduce (making his wife pregnant). This disability is called impotence and is considered as shameful and criminal behavior. It is because at that time, sex was considered important in marriage and it aimed only for human reproduction.

According to Foster (1999), sex or intimate relationships in marriage in the 17th century England, was not seen as a discourse of sexuality, rather, it was seen only as a media for reproductive activities (heredity). In other words, all forms of non-heterosexual sexuality, such as homosexuals, transgender people, and even impotence were considered deviant behavior and thus criminalized. So not only in Madura, but also in other countries of the world, impotent man can be divorced by the wife. The difference is that British men may be divorced by their wives because of impotence (non-reproductive), while Madurese men are divorced because of them being tak lake', which is a social construction of a man's masculinity.

The practice of divorce for male bodies due to their impotence or tak lake' shows that a body is not just a biological body with zero value. Rather, it is also a social body full of meaning, which can be constructed by various ideologies. The body becomes a person bearing cultural practices so that it becomes an arena of contestation of various ideologies, and Bordo (2003) calls it as the politics of the body. According to Bordo, the body is always in the grip of culture and is manifested in cultural practices and habits of daily life, just as the so'leran body is constructed by Madurese people as a broken body and will not be 'well-sold' anymore.

The so'leran body is in the grip of culture, which fully participates in all the social practices that govern and limit it with a set of rules that allow and forbid it. For example, he is unable to remarry and bears the stigma of being tak lake' for the rest of his life. In the body of the so'leran there is an arena of contestation of various ideologies as an intimidated body, dominated or ruled by powers. That is why, so'leran as a political body in Foucault's thought is built in a discourse of the body as a unity between knowledge and interconnected power.

The so'leran body cannot be released from the discourse of sex and power. Foucault stated that the two important elements which became the main drivers and encouraged the change of civilization were power and sex. The two cannot be separated, because power is sex, and sex is power. Sex needs a body, because according to Foucault, besides being a form of power, a body is also a tool for instilling and cultivating moral values in religious, political, social and economic activities.

In the body, power works by controlling, restraining and governing, so it is not enough to understand the body and sexual behavior only from the narrative of science, but it must also be understood how power works in it. That power is a discourse constructed by society, culture, economic, and politic (Foucault, 1997: 18), especially those related to gender power relations between men and women in a domestic circle.

Historically and culturally, a body is a tangential point of contact from the power relation between social control and resistance (Foucault, 1997, Brown \& Gershon, 2017). It is because the body becomes an important area where construction begins, for it contains contestation as its breath, and conflict as its pulse. A body is not just a pile of flesh and bones, but becomes an arena of war where the transformation of the body becomes a sign of fighting for influence. A body can, not only be seen, but also constructed, arranged, monitored, controlled, and formed whose domains work on the male and female bodies. This is what is called as the politics of the body.

Citing from the thoughts of Brown \& Gershon (2017: 8), in his dissertation, Umam (2014) stated that the politics of the body is "The inherently political nature of symbols and practices surrounding the body politics and the human body." Meanwhile, Foucault (1980: 56) offered his thoughts on the politics of the body to be built in a discourse of the body to create democratic and productive body relations, as a unity between technology, knowledge, and interrelated power. Thus, among various interests, the body becomes a very important issue in the politics of the body, because of the potential power that comes from the body itself can be used as a tool to fight back or vice versa (Foucault, 1980: 56). 
Research conducted by Daniel Susilo and Abdul Kodir about the frequency of women experiencing politics of the body, as mentioned in the "Politik Tubuh Perempuan: Bumi, Kuasa and Perlawanan" (2016), states that women's bodies have become the objects of the ruling regimes to control the rate of population growth by using contraceptives in the form of birth control pills, hormone injections, susuk implants or IUD, diaphragms, and condoms on women's bodies. This research which uses the perspective of Foucault's discourse of power, explains that women's bodies are regulated and controlled so that they do not have a thing on their own bodies that even bodies resisting the control will be sanctioned.

This causes women to be trapped inside their own bodies from signs, roles and functions affixed to their bodies by social and political construction. Furthermore, women who cannot get pregnant (reproduction) are also unable to escape from that construction by having feelings of guilt because they cannot have offspring. In her writing "Wacana Politik Tubuh Perempuan, Dalam Film Test Pack' (2015), Ratu Cahaya stated that social construction applied to women's bodies is caused by putting standards, categories, and characters as if the women's bodies are not their own personal property, but rather an environmental, social, economic, political and cultural property.

A body that no longer has power in its ownership and has become a public consumption, will experience symbolic violence, even in the name of self-existence. For example, an ad that carries a woman's body as the star of the advertisement has made the body a surrendering and submissive body.

As also explained in Foucault's thought, the body becomes an area where power relations run on it. Those power relations train, force, torture, mark, instill strength and control the body (Foucault, in Hardiyanta, 1997). The body becomes a power and is useful as long as the body is productive and submissive. Conquest of the body is a part of how power works over the body. As in the case of the body of the models, who are victims of symbolic violence but are considered to be self-existence.

In addition, the body according to Foucault (1980: 139), is everywhere and becomes the axis for the social life of society, whether it is obedient or sexual, crazy or evil, productive or sick, personal or political. When we talk about the politics of the body, we are actually talking about how the state and society govern the individual body, and about how the efforts of the individual body to defend themselves. The body is like an object represented at once as an organism that is managed to represent understanding and desire (Adler \& Pointon, 1993: 125), and language is a medium to convey or express that representation through discourse or text (literature) related to history (Foucault) 1989: 45).

In his article entitled "Konstruksi Politik Tubuh dalam Teks Sastra Poskolonial," Akhmad Taufik (2015) stated that a body in the study of postcolonial literary texts is not merely an empty biological dimension. But it becomes a dimension which comprises ideological, political, economic and cultural content. The second research related to the politics of the body in the study of literary texts was conducted by Ida Nur Chasanah (2015) in her dissertation entitled "Politik Tubuh dalam Karya Perempuan Pengarang Indonesia Era Reformasi." By using Foucault's discourse analysis method, she concluded that the discourse of the body in various forms had strengthened the body's position as a strong social arena to emphasize the power relations between women and men. This shows that women not only subordinate other women, but also subordinate themselves in the structures of male domination and various social institutions.

Therefore, in accordance with the terminology of the politics of the body, that the politics of the body is not merely about how the body is constructed and controlled or how these constructions and controls operate in daily life, but it is also about one fundamental fact that there will always be bodies that failed to be constructed and controlled.

\section{METHODS OF RESEARCH}

Foucault offers a genealogical perspective to read and analyze the war of power over the soleran body. The purpose of genealogy is to dismantle and question episteme (discourse), social practices and the human self. This concept carries the consequence that 
to know the power over the so'leran body requires research on the production of knowledge that underlies that power (Ratu, 2012), because each power is structured and established by certain knowledge and discourse.

"Power produces knowledge, power and knowledge directly influence each other and there is no power relationship without a correlative constitution of the field of knowledge" (Foucault, in Hardiyanta, 1997).

By using Foucault's perspective of genealogy, the researcher applies case study research or field study research. This method is intended to study intensively about the background of the problem, the situation and position of an event that is currently taking place, as well as the specific social unit environmental interactions that are naturally given.

Case studies are included in the descriptive analysis research which is an application in qualitative research, where the research carried out focuses on a particular case to be observed and analyzed thoroughly until it is completed. The case in question can be single or plural, for example in the form of individuals or groups. Here, it is necessary to conduct a sharp analysis of various factors related to the case so that finally an accurate conclusion will be obtained (Sutedi, 2009: 61). Furthermore, Arikunto (1986) argues that the case study method as a type of descriptive approach, is an intensive, detailed and in-depth study of an organism (individual), an institution or specific symptoms with a narrow/particular area or subject.

The application of this descriptive qualitative method using a case study approach that is inseparable from Foucault's genealogical perspective frame, is intended to carefully examine the case of the men's so'leran body that are called tak lake' in Madura. How the social culture of the Madurese community constructs the so'leran body into an entity.

\section{RESULTS AND DISCUSSION}

Masculinity or being lake' in Madurese tradition is understood through two things; first as a symbol of self-affirmation in front of the public, especially related to the right-wrong position, one of which through the courage to make decisions related to the principles of life and self-esteem. For example by declaring "carok" when someone disturbs his wife. Second, in the private/domestic circle (in bed), where men are not only able to meet the economic needs of their household, but must also be able to meet the sexual expectations of their partners and be able to have offspring.

Madurese male's masculinity is a social construction constructed in two phases, namely the phase before marriage and the phase after marriage. The phase before marriage is characterized by several stages including following below.

Going out of the House. What is meant by going out of the house here is entering the boarding school (pondok pesantren) after graduating from Elementary School (SD) until the High School (SMA) which can also be continued by wandering (merantau) outside the area of Madura. Here, wandering can be interpreted as both an effort to continue school to a higher level of education, or to migrate and find a job. Going out of the house for Madurese men is a condition for being a lake', because if a boy only stays in the house, it will not make a difference to a girl whose job is to accompany the parents. Since the task of boys is to maintain the stability of household life by working to earn a living, or forging social networks by expanding relationships. For Madurese boys, entering the boarding school is considered a prerequisite for reaching the stage of lake'. It is because by going out of the house and entering the boarding school, a boy will become an independent person. He is expected to not be a burden for the parents, and above all, he can also help and benefit the community and will easily find a job and earn his own income. Independent in this case also means by being able to solve problems quickly and accurately.

In general, going to a boarding school or mondok is understood as a compliance of the Madurese social cultural expectations toward the fulfillment of one's knowledge in religious sciences and the formation of morality (akhlak/tengka). This is true and applicable because Madura is identical with a very thick and strict religious knowledge. Madurese people are known as highly religious communities with a strong foundation of obedience and adherence 
to the teachers (guru/kyai). Morality is the basis of social, cultural and religious life for the people of Madura, thus having high morality is a fixed price. A man who has bad morality is considered tak lake' because they are unable to be a role model or an example for others. In addition, that kind of man is also considered to have no religious knowledge, because religion and morality cannot be separated.

Proposing a Woman. Proposing a woman to be married as a wife is a way for Madurese men to strengthen their masculinity, both in the public and private spheres. Because proposing a woman requires high courage as proof of a man's manhood in the public sphere. While in the private sphere, as a means of proving their ability to make his couple (wife) happy and to have children (Mutmainnah, 2018)

The next stage after the proposal is a khitbah or engagement as a symbol of a man's ownership of a woman so that no other man proposes or "takes" the woman. Because if it happened, then carok cannot be avoided. Carok occurs when there is interference from other parties by taking other people's property, such as land, fiance, wife, and others in an inappropriate manner. Wiyata's research (2002) found that problems related to women dominated the reasons for Madurese males' carok behavior. This is what then confirms the masculinity or maleness of Madurese men, because by proposing and getting engaged to a woman, he has ownership rights over the woman.

This concept also confirms that Madurese people adhere to a patriarchal system, where women are no different than men's "property." Forever, women have no freedom to decide for themselves. After being a child which is her father's property, then when proposed, she became the property of her future husband as a fiancée and remained her husband's property after marriage.

Getting Married. There are some Madurese who argue that married men have nothing to do with a man's lake' or tak lake' (masculine). Getting married is only a sign of maturity. It means that married men are individuals who are considered to be towah (read: adults). It similarly happens to women, because someone who is married is considered to have a great sense of responsibility, and prioritizes the interests of others over his/her own interests.

However, some people view marriage as a way to increase men's masculinity, because in marriage, a new character will be created or emerged in a man as a person who is more responsible and mature. This affirms the characteristics of masculinity in general. Aside from being responsible and mature, marriage is also believed to be an evidence of a man's courage and bravery to take responsibility for the lives of others, namely his wife, his children and his two extended families. (Mas'udi, 2016)

In the after marriage phase, the most decisive thing to know about Madurese male's masculinity is marked by the warfare on the first night. For the Madurese community, a bed is an arena of contestation of domination between women and men, especially during the first night after marriage, because it is where a man's masculinity will be determined and tested.

First Night's Fight. If a man fails or is unable to meet the wife's sexual expectations due to his lackluster (premature ejaculation) on the first night, then his struggle will get tougher the following nights. If it still feels like a failure for the next one week, then the destruction of his household is inevitable, because his wife might be able to leave him. It is whether the wife will return to her parents' house, or will ask her husband to leave their house. If that happens, then this is a big disgrace for the husband since he will automatically be labeled as tak lake'.

This issue is in great attention for men who are about to get married. They are making preparations before marriage, for example by taking herbal medicine for the 'fight' (strong herbal medicine specifically for men) and doing some special care. This kind of disciplining the body activities being done by Madurese men who are going to get married is a portrait of an attempt to reinforce their ego or self-belief in the concept of masculinity in the social culture of the Madurese community.

Disciplining of the body by men who are about to get married does not only include physical discipline but also mental and spiritual discipline. This is marked by the consumption of eggs, herbs and all kinds of suggested foods and drinks just to keep from disappointing his wife during their first night. Meanwhile, mental and spiritual preparation is also done to get 
the blessing and advice, so that he will be able and ready to take on a new life with the woman of his choice.

All these disciplinary efforts are a form of rejection of failure that might occur on the first night, as that night is the night that determines the continuity of his maleness which also means the sustainability of the future of his household. The first night is the night of determinations for a man's maleness and masculinity, which are not only tested for their sexual masculinity, but also their masculinity as social beings as men who are lake'. It is because lake' is a fixed price for Madurese men.

Working for a Living. The next stage that must be traversed and maintained by Madurese men who are married is by working and earning income (earning a living to fulfill their household needs). If a Madurese man who is married does not support his household (wife), then he is considered tak lake' because he is shown to be irresponsible and is not mature.

According to an article published on September 22, 2019 in Surya daily newspaper entitled "Setiap Pekan Banyak lbu Guru Minta Izin Bercerai," indicates that not only is the problem of a not working husband, but also when the husband's income is lower than the wife's income, a potential reason to trigger a divorce is also visible.

Since the existence of certification incentive funds for honorary elementary school teachers was announced, the Pamekasan Education Office has been inundated with elementary school teachers who ask for permission and recommendations for divorcing their husbands. Prama Jaya as the acting official (PIt.) of the Head of the Pamekasan Education Office said that the three highest reasons for female teachers to sue for divorce were: 1) The husband is considered to not providing sufficient amount of money for their daily spending, 2) Husband's behavior that turns into an over jealousy, and 3) The presence of a mismatch or incompatibility between husband and wife. Prama also added that this has happened since the existence of certification incentive funds for SD (Elementary School) Pamekasan teachers, the amount of which is almost equal to the salaries of PNS (Civil Servants) teachers.

Meanwhile, there are two categories of backgrounds of female teachers who apply for divorce; $85 \%$ of those who are young and not yet have children with a marriage age of $1-5$ years, and $12 \%$ of those who are around $40-50$ years old middle-aged women that even already have daughter-in-laws and grandchildren.

$95 \%$ of their husband's work background is non-civil servants. Some work as traders, honorary teachers, farmers, and informal. What is meant by informal here is referring to the project worker; when there is a project, that's where he works and makes money, while if there is no project, "they just stay inside the house without making a penny," said Devi, one of the honorary elementary school teachers who asked permission from the Pamekasan Education Office to sue her husband at Prama Jaya.

The Pamekasan Religious Courts Office stated that $80 \%$ of the reasons for a wife to sue for divorce were due to the husband's lack of responsibility for providing a living. This fact was confirmed by Sulaisi Abdurrazaq as a lawyer who claimed to often become a legal counsel for divorce, and was strengthened by the news reported by the Radar Madura daily newspaper with the headline of, "666 Istri Ramai-ramai Gugat Cerai Suami" on last September 22, 2019.

Having Children. The proverb of "The more children the more fortune," is a proverb that is really applied in the socio-cultural life of the Madurese community, because the number of children and grandchildren that one has reflects the wealth of the related person. In other words, the large number of children and grandchildren that someone has is a measurement of success and the reliability or establishment of a person in his life journey, especially for men. This means that men who are married and have children are considered more successful than men who do not have or not yet have children despite having high positions or never-ending luxurious properties.

Based on the survey, the biggest cost in household needs is the cost for children, be that for the cost of their care, education, entertainment, and health. Meanwhile, as explained earlier, that money is also a measurement of the quality of men's lake'. The more children, 
the greater the expenditure of household costs needed, especially to those who have their children going to the higher level of education such as university level.

Those successful children will add to the success of a man as a head of the family, even though he is guaranteed to work harder to make a living for his family. Furthermore, at some point, Madurese men also dared to decide to adopt children (ngala' anak). In the Madurese tradition, adopting children is a glorious behavior, especially for men who are married (married). That is because men are considered to have the value of courage and great responsibility. The more children adopted, the greater the value of someone in the eyes of society to be respected and valued.

Carok. On December 10, 2019, the Pamekasan city community was shocked by the attempted murder carried out by one of the soldiers named Serda Ali Sahbana who was a village's non-commissioned officer of a military commander (Babinsa Koramil) 0826/08 Palengaan military District Commander (Kodim) 0826 Pamekasan against members of the Police, Bripka Imam Sutrisno who was on that time serving as part of the IDIK Unit III Satreskim Polres Pamekasan. The incident was allegedly triggered by an affair committed by Bripka Imam Sutrisno to the wife of Serda Ali Sahbana who was originally an elementary school teacher named Selvi.

A murder case with infidelity as a motive also occurred in the sub-district of Tanjung Bumi Bangkalan on October 24, 2019, where the perpetrator named Sahri (32) killed the victim named Rahmat (30) because of his resentment toward the victim who was having an affair with the wife of the perpetrator. The victim's life could not be saved, while the perpetrators were threatened with Article 340 of the Criminal Code sub article 338 of the Criminal Code with the penalty of life imprisonment. Meanwhile, in Blumbungan Pamekasan village, there was also a murder incident with the motive of an affair on August 9, 2019, which was carried out by Ahmad (26) towards Hanif (26), causing the death of the victim. This incident began when the perpetrator returned from Malaysia, and heard the news that his wife was having an affair with the victim while he was working in Malaysia as a TKI (Indonesian Workers). Without confirming, the culprit who was burned by jealousy immediately went to Hanif and stabbed a knife in the victim's stomach, back and neck.

There are two important notes in the three events mentioned above. First, the motive for infidelity is often becoming the main reason for the murder. Second, the carok tradition is starting to be littered or polluted with the concept of fighting that comes out of the carok rule. Carok was interpreted as a duel or fight (Zulkarnain, 2003: 75) to death conducted by two men using sickles (celurit). Here, carok was understood as an effort or a last resort by the Madurese community to solve a problem that never ends. The problem here is related to the self-esteem that is trampled by others relating to property, throne/power and women. So carok is considered a way for Madurese to defend their pride. However, in Madurese culture, carok is not done by freely slashing others. There are rules and conditions for a man before deciding to do carok to solve his problems (Wiyata: 2002: 45). And in this case, the researcher only focuses on carok by assessing the disturbance of Madurese male's pride by others.

The essence of the carok's aim is the defense of men's self-esteem, especially in relation to the interference with his wife, which makes Madurese men feel ashamed (maloh) and lowering their dignity as men who are tak lake'. The problem of women with carok is like two sides of a coin that cannot be separated from each other, this is also the beginning of the symbol of the weapon used for carok, the sickle. Madurese men's habit of carrying sickles and putting it on their left side of the waist, is understood as an effort to defend the selfesteem of Madurese men. It is also understood as a compliment to their body since there is one rib missing from men's bodies. Then sickle is defined as a woman who is a man's rib. When his wife is disturbed or having an affair, then a man seems to lose his self-esteem and he must do the carok (Zulkarnain, 2003: 80) to restore his self-esteem.

Cheating and Polygamy. Entering the after marriage phase, it turns out that winning the 'fight' on the first night and being a husband who is responsible for all the needs of his wife and children is not enough to show that the masculinity of Madurese men is strongly 
attached to him. Then cheating and polygamy become the next alternative to further strengthen the image of him being a lake'.

Cheating is a conquest made by men against women. The more women are conquered, the stronger the inherent masculinity will be. It will be more interesting if the conquered woman belongs to someone else (someone else's fiancee or wife), which means that his masculinity will be declared to be even stronger, even though his own life is actually at stake, because that will result in a carok. The conquest that is meant here is to make a woman as a girlfriend or a mistress. The man is not ashamed and is not afraid to introduce his affair/mistress to his friends just to show off his lake' quality.

Meanwhile, the majority of polygamy practices are carried out by elites, namely religious elites (religious leaders), economic elites (entrepreneurs) and political elites (politicians) with the aim of increasing their masculinity as Madurese men. The practice of polygamy carried out by religious elites is more emphasized on the purpose of da'wah by building boarding schools in different locations where their wives live. The more pesantren they build, the higher their social strata will be in public.

Polygamy practiced by entrepreneurs confirms Wattie's research (2008) which states that wealth is the foundation for entrepreneurs to strengthen their ability to do polygamy. For them, fairness which is the main requirement in polygamy is understood as fairness in the distribution and provision of living. So, a businessman with a high amount of wealth has the high opportunity and chance to practice polygamy. It is similar to what expressed by Pierre Bourdieu, that economic capital is superior to other capital to dominate others, including the practice of polygamy.

\section{Division of the role and position of madurese men and women:}

The concept pattern of taneyan lanjheng has a significant influence in determining and shaping the roles of men and women in the domestic circle. The kitchen located at the back side of the house is a space for women to cook while the living room at the front side of the house is a room for men to welcome guests. The pattern confirms that the position of women is lower than the position of men whose job is to welcome guests at the front side of the house.

In addition, the religious text stated that the obligation of men as husbands is to make a living to meet their household needs in the public space or outside the house, while the wife is obliged to take care of and serve all household needs which incidentally are all done in the domestic space. At a glance, this division of tasks seems to be ideal and fair. But without realizing it, women's space is limited only in the domestic space, which is narrower than the public space reserved for men.

This limitation of space for women is what makes their actions or behavior easily highlighted by judgment without argument. For example, the one happened to Santi (24) who decided to stop working after six months of marriage because she became the talk of the neighbors. Whereas her goal to keep working is solely to help her husband to meet their household needs. The husband does not forbid her to work, but the culture in the community made Santi to be judged as a wife who does not know how to position herself, because she often returns home after her husband arrives home.

This shows that the role of women in the domestic circle is not merely male domination, but also the construction of cultural forces which is manifested in the community's response toward their behavior. The role of the wife who is only in the domestic space (home) makes it even more solid and dense with the presence of a child in the midst of the family. Her job is not only as a wife who serves the needs of her husband, but also as a mother who takes care of and meets the needs of her children. The more children they have, the more tasks for women in the domestic circle, while the husband's duty is still the same from the start, which is earning a living outside the home. This is what is called the patriarchal system, which places women as the only parties in charge of domestic work.

However, this is different from what happened to the Branta Pesisir Pamekasan community, who involved wives in their public spheres. In Mulyadi's research (2011) written in the journal of KARSA explained that when husbands who work as fishermen look for fishes in the high seas, the wives in addition to taking care of domestic household needs 
(husband and children) also sell the fishes caught by the husbands in the market which is located on the side of the street. This happens due to social, economic and cultural changes that influenced the views of some people about the role of women and men in marriage.

Although feminism considers this pattern to be a dual role for a wife (woman) which is seen as an unjust practice, according to field facts, however, the Pesisir Branta community has a different view. They reveal that looking for fishes in the high seas is not an easy task, because ones' lives could be at stake. So the wives took the initiative to participate in the public sphere by selling fish caught by their husbands. This is a kind of social change caused by the globalization of information and the modernization of technology, where the concept of exchanging roles between husband and wife appears. The husband who initially was in the public sphere as a breadwinner, and the wife was in the domestic sphere, exchanged their role. Thus, it is now the wife who made a living in public space, while the husband stayed at home looking after the children and taking care of the household (of course after handing over the fishes he caught ).

Swapping roles between husband and wife in the domestic sphere is increasingly massive and accepted by the community. It is no longer a strange and taboo thing, but rather a trend in some Madurese communities. When the phenomenon of the Stay-home Father increasingly burst out, on the other hand, the wives got what they wanted, namely access to work in the public sphere with promising careers. Society is no longer concerned about the exchange of roles, or dual roles of women, because it has been applied by most societies today.

So'leran: a man's wasted body:

Masculinity is very closely related to the body. The body itself is used as the legitimacy of the hegemony of men's masculinity, both to subordinate women and also dominate other men, because it is defined as a configuration of gender practices that guarantee the continuity of culture or the patriarchal system, which places the highest position to the domination of men (Connell, 2005: 77-78). As in the case of women's bodies, masculinity also undergoes construction as a result of the existence of a social system.

Women as a wife are the main determinants of Madurese men's masculinity, due to the tak lake' recognition of a man starting from the wife. So if a woman states that the man she married is tak lake', all the household expectations he imagined at the beginning of the marriage are done and perished. Besides that, the masculinity of Madurese men in their households area is tested with their capacity as the head of the family who is able to meet the needs of the household in terms of financial support (economy). For this reason, when a man does not work, or even gaining salary less than the wife's salary, then his household has the potentiality to experience destruction, for he is considered a failure to become the head of the family. This kind of failure can also cause infidelity or divorce by the wife as a form of confession for the husband's tak lake' condition. So, it is understood that the relationship in the household is the main locus (place) for the existence of the power over a man's body or a so'leran body.

So'leran is a man who is sued for divorce by his wife, and then the ex-wife remarries to another man who is younger and richer than him. Men who are sued for divorce by their partners are called tak lake', which is more appalling to men when there is a practice of so'ler happening after then. The stigma of the soleran body is thickly understood with the powerlessness of men as an entity that should originally be able to actualize the expectations of masculinity in the culture of Madurese society. If the masculinity aspects cannot be fulfilled, then social sanctions (including depression) will be borne by men with the predicate of so'leran body in an indefinite period of time. Some Madurese men wished that they could even end their lives sooner rather than having to face other's stares and insults at the collapse of their masculinity because they were called as tak lake'.

Then what should a man who has been judged as tak lake' to become lake' again? Facts found by the researcher in the field about how the lake' predicate can be re-owned by men who are already attached to the title of tak lake', can be done in two ways, namely:

- By doing carok or killing the man who interferes (cheats or marries) his wife, a man will regain public recognition of his masculinity (his lake' qualities). This method has 
been practiced by many Madurese men, even though they have to bear the risk of being held in prison. Prison is not a frightening specter for Madurese men, compared to having to last a lifetime bearing the title of tak lake' and being excluded from his social life. Moreover, this carok can restore his self-esteem that has been destroyed by being sued for divorce by his wife.

- The man who is so'ler or being called as so'leran, will soon remarry as an effort to restore his pride as a Madurese man. As quick as possible, this solution should be done precisely before his ex-wife remarried. Of course, it is for him to escape the assumption of tak lake'. The gruesome assumption of being tak lake' encourages Madurese men to immediately precede the remarriage, even if it necessarily means that he has to marry whoever wants to marry him. There is no other expectation of the marriage except to precede his wife's marriage and to release the title or tak lake' from himself. So whatever the method is, maintaining the existence of Madurese men is the main and most important form of strengthening their self-esteem.

The genealogy of so'leran body:

Foucault (1976) said that power is everywhere and that in any form of every relationship there must be power in it. Including the relationship between humans and the social culture in which they live and also the relationship between men and women, which determines the Madurese men's masculinity with two valuations, namely lake' (macho, manly, and masculine) or tak lake' (weak, sissy, and pygmy).

Based on the findings in the field study as previously mentioned by the researcher, there are several conditions for Madurese men to become lake' namely: leaving the house by going to school or studying and working, then proposing and marrying women, then having many children, and finally doing carok if his pride is hurt. In other words, men who do not meet these requirements will be called as tak lake'. This is also actually a product of the power of the patriarchal culture of Madurese society, which puts men at the forefront and must not lose against women in all social interactions.

In addition, the demands of men to be a lake' are also a result of the hegemony of masculinity which for Connel (2005: 77-78) not only women who are marginalized, but also men who are victims of the patriarchal cultural system. Men are demanded to meet the requirements to be lake' in order to remain in the front position of women. Meanwhile, by using an essentialist perspective, Connel (2005: 68-70) argues that masculinity is also determined by hormones in the male body. It means that, being masculine is not only constructed by social culture, but also determined by the biological factors of the body.

The power of a patriarchal cultural system and hegemony of masculinity over Madurese men to become a lake', by Foucault (1997: 155), is called as the genealogy of the body, which aims to show how power and knowledge relations can be manifested into the body, namely the body of Madurese men to become lake'. The process of the genealogy of the body in the Madurese male body is explained by the researcher as follows.

The Normalization Process of Madurese Male Virility. The use of power and knowledge cannot be separated from the concept of normalization, namely the institutional hegemony over the change in discourse which results in the distinction between those considered normal and those considered abnormal. For example, in the past, a woman was considered normal if she had many children, based on the widespread believed expression that "The more children the more fortune." But after a regulation was set up in the form of a family planning (KB) program during the new order, which obliged women to have only two children, as a result, nowadays, women who have more than two children are called abnormal, while women who have two children are considered normal, since they have complied with government programs.

Being a lake' is a matter of pride for Madurese men, because it can actualize the expectations of masculinity that Madurese people believe as absolute truths. Men are the successors to the family line of the Madurese society who follow the patrilineal system. It means that having a son is more glorious than having a daughter. However, this does not apply when the son is unable to meet the standard requirements to be a lake' that are already set in Madurese culture, then he will lose his self-esteem as a man with the title of 
tak lake'. Meanwhile, the term tak lake' is something that is very frightening for Madurese men who adhere to a patriarchal system, that even the title can cause him to be alienated or driven out of his own hometown.

The capacity of Madurese men comes from the construction of a Madurese culture system to meet the requirements of being a lake'. Not only limited to fulfilling the social and physical values, but also must include the cultural values. Those social values include being responsible, brave, towah (adult), and honest, while the physical values is to have a strong body, muscular, manly, able to win the 'bed fight', and not impotent. These two values of male masculinity also apply outside the area of Madura, because they are general values understood extensively. Meanwhile, cultural values such as, proposing for marriage, getting married, having many children, applying polygamy, cheating, angko or gendhe' (read: prestige or arrogant) and carok (killing) for those who insult their self-esteem, are characteristics of Madurese men as an absolute requirement to be lake'.

When Madurese men have the capacity in all these three values, then they will be recognized as lake' and normal men. Meanwhile, men who cannot fulfill all three values of masculinity are considered to be abnormal.

The Relationship of Power and Knowledge over the Soleran. According to Foucault (in Eriyanto, 2003: 65) the relationship between power and knowledge is mutual and reciprocal, where power creates a knowledge entity, while knowledge causes the effect of power. Or in other words, there is no knowledge without power, and vise versa. Meanwhile, knowledge which is in the form of discourses, produces a truth from the results of the collective justification of society. The justification is the effect of power or authority, because power or authority according to Foucault is not a power to control people or institutions, but as an act of repression or oppression (Haryatmoko, 2002: 10).

The predicate tak lake' to men who are being so'ler alias So'leran by the community, is an effect of power through the Madurese male masculinity discourse which is constructed and produced by Madurese social culture. The discourse then becomes a truth through a process of internalization in the community by justifying without verification or clarification. This truth also shows that power operates unconsciously into the network of public awareness, because power according to Foucault (in Haryatmoko: 2002) does not come from the outside, but from the within through rules, regulations, laws, and even traditions and culture. Meanwhile, tradition and culture are understood as a society's way of looking or living through mutual agreement to be guarded, maintained, cared for and inherited from generation to generation to become an image or characteristic of a society that distinguishes it from other community systems.

The relation of power and knowledge of the so'leran body by the name of tak lake' is caused by:

- Parabhesan Madura. So'leran is the object of the power of Madurese knowledge about masculinity or the manliness (lake') of Madurese men. Knowledge about standardization or the requirements to be a lake' for Madurese men is part of the construction of the cultural system of the Madurese community, which is based on parabhesan (phrase) "Lebbih bagus poteh tolang etembeng poteh matah" (It is better for the bone to be white than for the eyes to be white, which means, it is better to die rather than live in shame). This meaning is closely related to men's self-esteem as the fixed price. One of the meanings included in the phrase of "self-esteem" in that parabhesan is to be lake' by having three masculinity values, namely social values, physical values and cultural values. All three are knowledge that is constructed by the social culture of the Madurese community to dominate or possess men who do not meet or do not have some of the three values of masculinity to be called as tak lake'. This title is considered to be capable of destroying or undermining the dignity and self-esteem of men in the face of a patriarchal society. Madurese men's self-esteem is shown through the community's recognition of his capacity as a man, especially related to his masculinity. If the recognition is in the form of tak lake', this automatically means that his pride has been degraded, or in other words the community does not recognize his capacity as a man. One of the causes is, when he 
was sued for divorce and then being so'ler by his wife. The parabhesan also means that it requires reng Madureh, especially men, to reclaim their self-esteem that has been degraded through carok. It is because in parabhesan, there is the phrase 'poteh tollang' which means to die. While honorable deaths are meant only through carok. However, if the So'leran does not do the carok to restore his pride to be a lake' again, then he will still be considered a man who is tak lake' for the rest of his life. The interpretation of parabhesan that touches on men's self-esteem is part of the relation of the power of knowledge to the construction of Madurese male masculinity discourse. That power is manifested in the way the community recognizes the capacity of Madurese men as lake' or tak lake'. This means that the parabhesan has constructed the knowledge of the community about the capacity of Madurese male masculinity. This knowledge not only constructs the perspective of society about the discourse of Madurese men's masculinity, but also constructs the perspective of Madurese men themselves in shaping themselves into men who are lake', specifically by increasing their capacity as men, or reclaim his pride that had been harassed through carok.

- Collective Narrative as a Product of a Patronism System. The term tak lake' in so'leran, is a truth, where the truth is a match between propositions and facts. In other words, the community will not address tak lake' to the so'leran, without the fact that the men are indeed sued for divorce and then 'exchanged' with other men because their bodies do not meet the expectations of the Madurese masculinity. Proposition is a human statement made by the senses, while fact is an object made by the subject to the reality. And in this case, what is meant by the proposition is the attitude of the Madurese community towards the so'leran in the form of rejection or even to the eviction from their homeland, because in reality, so'leran is no longer considered to meet the requirements of Madurese male masculinity as a lake'. Meanwhile, being a lake' is a necessity for Madurese men, because it is related to their self-esteem in the patriarchal system.

Besides the correspondence theory, there is also a theory of coherence in understanding a truth. Coherence is the determination or consistency between propositions and assumptions. The meaning of assumption is a result of the mind in the form of a conclusion based on an idea or fact. Therefore, based on this theory, the designation of tak lake' to the so'leran is an assumption by the Madurese people about the masculinity of so'leran that is no longer considered lake' (Hefni, 2017).

The next theory of truth is intersubjective theory. Here, a truth is considered to be true when it is justified by many people. The contents of the truth are then called collective narratives. This is also the one confirming that in a sociological context, what is meant by truth is something that receives justification from many people. This collective narrative does not just fall from the sky, because there is another greater force that constructs the collective narrative, that is, elite narrative or patron narrative that comes from community leaders. They are the kyai or elders who are recognized by the local community as community leaders through the tradition of nyabis (visiting Kyai) or through delivering lectures at certain events.

The politics of the so'leran body: dreams and imaginations to be a lake':

When we talk about power and knowledge relations, it cannot be separated from the body, because according to Foucault (1978) the root of power lies in the body, and in its genealogy, the body is understood to be the locus (place) of power. Meanwhile, in the sociocultural context, the body is a representation of the socio-cultural community that concerns its system or structure (Bordo, 2003). So seeing the body means seeing the world, and how the power of the world works, can be seen from the body.

The body that is overpowered, controlled, dominated, and regulated is called the politics of the body. Like the power of the State over its people through the KB (Family Planning) program that can regulate and control the body in suppressing the population. Likewise, the power of science in the field of health (medical) or psychology (soul) which has the authority to determine the condition of a person's body, whether he is healthy or mentally 
ill. So the relation of the power of knowledge is never in favor of the body, and the body is always becoming a victim of that power, including the so'leran body.

Procedures or methods are needed to make the body obedient, which is the lake' body. Among them are disciplining the body. Discipline according to Foucault (1997) is the conquest of the body through careful and detailed control mechanisms by being continuously trained and repeatedly tested or corrected to form a useful body. In other words, discipline is a way of exercising control over the body to produce an obedient body, in order to be a lake', that is by consuming 'strong' herbs (jamu kuat), doing massages special for men, taking 'strong' pills or capsules, and using 'hajar jahanam.'

Punishment is the consequence of a disciplinary procedure that is set on the body. The punishment for so'leran who failed in disciplining his body is by being stigmatized as tak lake' towards his masculinity, and this title is considered to be very horrible for men who live in patriarchal system. That is why, the predicate of tak lake' is a very cruel punishment for Madurese men. They will have to work really hard to omit this predicate even though their bodies and lives are at stake in the practice of carok.

Panopticon is a part of disciplining the body that contains two methods, namely disciplining by physically touching the body with torture, and disciplining without having to touch the body, such as a prison in which not only regulates the body with exercises, or limits freedom of activity, but also conducts supervision (Panopticon). This is based on Foucault's analysis (1977 \& 1997: 26) towards the change in the form of punishment in Europe in the 17-19th century against criminals who did not obey the rules or rebelled against the authorities.

At the end of the 17th century until the beginning of the 18th century, the European kingdom imposed cruel tortures on the bodies of criminals and was publicly displayed. Then that punishment of torture as 'public spectacle' was erased and increasingly lost from people's memories in the 19th century. These changes happened because that kind of punishments are considered inhumane, and thus replaced with institutions, the formulation of rules and laws, the determination of the court system that ends in prison, wherein there are restrictions, training and supervisions as punishment.

Although the punishment in the prison is part of disciplining the body that does not touch the body directly, all the procedures still involve the body, such as restrictions on activity, forced labor, working on time, and so on. This shows that the body is an instrument or media of the continuity of the power of knowledge over the body, especially in terms of supervision or panopticon.

Actually the meaning of this isolation term by Foucault (1997: 111) is based on a case of saving the community in a particular environment from infectious diseases or bacteria. But in general, the meaning of isolation is understood as something separate and not connected to other things. Thus, the isolation of so'leran is done by cultivating knowledge in the community about so'leran as a useless person with a damaged body, so it must be addressed with an act of rejection.

\section{CONCLUSION}

The relation of power and knowledge to the discourse of the Madurese male masculinity has punished the male body as tak lake', especially in the so'leran body, for it is unable to meet the expectations of masculinity constructed by Madurese society. Men by the title of tak lake' are considered to fail to have three values of masculinity, namely social, physical and cultural values. So to be a lake is to have a high self-esteem as Madurese men in various spheres of life. Especially by winning the 'battle of bed' over his partner (wife), also by being able to become the head of the family who can meet the expectations of the household needs with greater income from his wife. This is a kind of social cultural construction of Madurese society over male masculinity through parabhesan and collective narratives that get their legitimacy from elite narratives (lectures from Kyai).

The results of the researcher's analysis from the hegemony of masculinity, confirmed that the politics of the soleran body constructed the gender relations of Madurese men and 
women in the domestic circle. So that men, through the concept of panopticon, create strategies in maintaining their masculinity in the face of a patriarchal Madurese cultural system by intimidating and limiting women's space in the public sphere. So that if the expectations of the application of that panopticon concept do not actualize as they should, depression is a type of punishment for men who fail to achieve the value of masculinity by practicing infidelity. Thus, it proves that the social system of Madurese society is a patriarchy.

\section{REFERENCES}

1. Adler \& Pointon, 1993. The Body Imaged: Human Form and Visual Culture Since The Renaissance. Cambridge: Cambridge University Press.

2. Bhasin, Kamla. 1996. Menggugat Patriarki "What is Patriarchy", Translated by Nung Katjasungkana, Yayasan Bentang Budaya Yogyakarta.

3. Brown, Nadia, \& Gershon, Sarah Allen. 2017. Body Politic. Journal Politics, Groups, and Identities. Vol. 5. No. 1 (p 1-3). USA: Routledge.

4. Bustami, Abdul Latif. 2006. Seksualitas Oreng Madure: Gelas Bergoyang and Sendok pun Bergetar. Jakarta; Srinthil.

5. Connell, R. 2009. Gender in World Perspective. Cambridge: Polity.

6. Connell, R, Messerschmidt, J.W. 2005. Hegemonic Masculinity: Rethinking the Concept. Gender \& Society 19 (6): 829-859.

7. Darwin, Muhadjir. 1999. Maskulinitas; Posisi laki-laki dalam Masyarakat Patriarkis. Center of Population and Policy Studies. Yogyakarta: Gajah Mada University.

8. Drianus, Oktarizal. 2019. Hegemonic Masculinity: Wacana Relasi Gender dalam tinjauan Psikologi sosial. Psychosophia, journal of Psychology, Religion and Humanity. Vol. 1 No. 1.

9. Eriyanto, 2001. Analisis Wacana: Pengantar Analisis Teks Media. Yogyakarta; Lkis.

10. Foucault, Michel, 1978. The History of Sexuality (Vol 1). New York. Ny. Pantheon Books.

11. 2002. Kegilaan and Peradaban. Translated. Yogyakarta; IKON.

12. 2007. Arkeologi Pengetahuan. Translated by. B. Priambodo \& Pradana Boy. Yogyakarta; Pustaka Pelajar.

13. 1977. Discipline and Punish; The Birth of the Prison. Translated to Bahasa Indonesia by Petrus sunu Hardiyanta, Disiplin Tubuh Bengkel Individu Modern. Yogyakarta: LKis 1997

14. 2002. Wacana, Kuasa/ Pengetahuan. Translated.Yogyakarta: Bentang.

15. 2007. Agama, Budaya, and Seksualitas. Translated. Yogyakarta: Jalasutra.

16. 2000. Seks and Kekuasaan. Translated by Rahayu S. Hidayat. Jakarta: Gramedia.

17. 2002. The Order of Thing. Translated. Yogyakarta; Pustaka Pelajar.

18. Habiba, Ume, Ali, Rabia. 2016. From Patriarchy to Neopatriarchy: Experiences of Women from Pakistan. Asia Ashfaq. International Journal of Humanities and Social Science. Vol. 6 No. 3: March.

19. Hardiyanta, S. Petrus. 1997. Disiplin Tubuh: Bengkel Individu. Yogyakarta; LKiS.

20. Haryatmoko. 2010. Dominasi Penuh Muslihat; Akar Kekerasan and Diskriminasi. Jakarta. Gramedia.

21. Hefni, Moh. 2017. Bhuppa-Bhabhu'-ghuru-rato (Studi Konstruktivisme-strukturalis tentang hierarkhi kepatuhan dalam budaya Masyarakat Madura) Jurnal Karsa, Vol 11 No. 1. Hal 15-17.

22. Laslett, Barbara, Brenner, Johanna. 2009. Gender and Social Reproduction: Historical Perspective. Annual Review of Sociology. Vol. 15 (p 381-404).

23. Lynne, Melisa Jakubauskas. 2010. Men's Consumption of Fitness and Exercise: An Exploration of Motivation for Exercise and Fitness Involvement. Journal Lowa: State University America.

24. Mas'udi. 2016. Kesetaraan Suami and Istri dalam Keluarga (Analisis Kesetaraan Pembagian Kerja dalam Keluarga Madura). Konseling Religi: Jurnal Bimbingan Konseling Islam. Vol 7 No. 2.

25. Mohammed, S.G. 2011. Idealized Masculinity: Image of White Men's Bodies and White Men's Ideas About Masculinity. Washington, Ditrict of Colombia: Proquest Dissertations. 
26. Mutmainnah. 2018. Persepsi Masyarakat tentang Mitos Sangkal Peempuan Penolak Lamaran di Desa Penagan Sumenep Madura. Jurnal Pamator. Vol 11 No. 1 April. Hal 1-9.

27. Radar Madura Daily Newspaper entitled "666 Istri Ramai-ramai Gugat Cerai Suami” on September 22, 2019.

28. Raditya, Ardie, MA. 2014. Sosiologi Tubuh; Membentang Teori di Ranah Aplikasi. Yogyakarta; Kaukaba.

29. Ratna Megawangi. 1999. Membiarkan Berbeda: Sudut Pandang Baru tentang Relasi Gender. Mizan: Bandung.

30. Rifai, A. Mien, 2007. Manusia Madura. Yogyakarta. Pilar Media.

31. Ritzer, George \& Goodman, J. Douglas, 2004. Teori Sosiologi Modern. Translated. Jakarta, Kencana.

32. 2012. Teori Sosial Posmodern. Translated. Yogyakarta. Kreasi Kencana.

33. Rosalina. 2012. Maskulinitas Pada Iklan Televisi. Universitas Indonesia. Departemen IImu Komunikasi.

34. Sasmita, Ulin. 2017. Representasi Maskulinitas dalam film Disney Moana (Analisi Semiotika Charles Sanders Pierce). Jurnal Online Kinesik. Vol. 04. No. 2.

35. Simone, De Beauvoir. 2003, Second Sex,Translated. Pustaka Promethea, Surabaya.

36. Sondakh, Priska Cinrhia. 2014. Maskulinitas di Majalah Pria. Surabaya: IImu Komunikasi Universitas Petra.

37. Synnott, Anthony. 2007. Tubuh Sosial. Translated. Yogyakarta. Jalasutra.

38. Suyono, Joko, Seno, 2005. Tubuh Yang Rasis, Yogyakarta. Pustaka Pelajar.

39. Susilo, Daniel, Kodir, Abdul. 2016. "Politik Tubuh Perempuan: Bumi, Kuasa and Perlawanan" Jurnal Politik. Vol 1, No. 2.

40. Tong, Rosemarie Putnam. 1998. Feminist Thought. Translated by Aquarini P. Yogyakarta, JALASUTRA.

41. Trikuncoro, Dia Kusumawati and Mursito. 2013. Maskulinitas dalam Iklan Majalah Pria. Surakarta: Universitas Sebelas Maret.

42. Wardani, Agista Nidya. 2018. Hegemoni Maskulinitas dalam Under The Greenwood Tree Karya Thomas Hardy. Satwika (Jurnal Kajian Budaya and Perubahan Sosial) Vol. 2 No. 2 Oktober. 